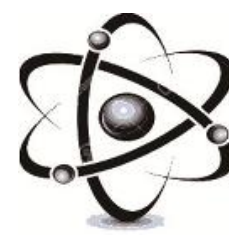

JURNAL RISET FISIKA EDUKASI DAN SAINS

Education and Science Physics Journal

E- ISSN : 2503-3425

P- ISSN : 2407-3563

JRFES Vol 1, No 1 (2014) 19 -27

http://ejournal.stkip-pgri-sumbar.ac.id/index.php/JRFES

\title{
PENGARUH MODEL PEMBELAJARAN WRITE PAIR SHARE (WPS) DALAM MENINGKATKAN KOMPETENSI PEMBELAJARAN FISIKA DITINJAU DARI PENGETAHUAN AWAL MAHASISWA STKIP PGRI SUMATERA BARAT
}

\author{
Silvi Trisna ${ }^{(1)}$ dan Putri Pratiwi ${ }^{(2)}$ \\ ${ }^{(1)}$ Prodi Pendidikan Fisika STKIP PGRI Sumatra Barat \\ ${ }^{(2)}$ Prodi Pendidikan Biologi STKIP PGRI Sumatra Barat \\ Emailvvina_sanguine@yahoo.com \\ http://dx.doi.org/10.22202/jrfes.2014.v1i1.1182
}

\section{Abstract}

The learning model Write Pair Share (WPS) to allow students to be more active in analyzing any problems so that they can develop the capacity to think. But this can not be done if the students do not know and understand the original concept of the material that will be provided, so that takes an initial knowledge prior to the commencement of the course. This type of research is a quasiexperimental research design study The randomized pretest-posttest control group design. The instrument used was the ultimate test essay form. Data were collected through initial knowledge as a pretest and a posttest learning outcomes, and then analyzed by t-test. The result showed that: (1) There is a significant difference model application Write Pair Share (WPS) on the results of learning competencies; (2) There is a significant difference model application Write Pair Share (WPS) on the results of students' physics learning competencies that high initial knowledgeable; (3) There is no significant difference model application Write Pair Share (WPS) on the results of students' physics learning competencies low initial knowledgeable

Keywords: Early Knowledge, Write Pair Share (WPS), the competence of learning physics

\begin{abstract}
Abstrak
Model pembelajaran Write Pair Share (WPS) memberikan kesempatan kepada mahasiswa untuk lebih aktif dalam menganalisis setiap permasalahan sehingga mampu mengembangkan kemampuan berpikirnya. Tetapi hal ini belum bisa terlaksana jika mahasiswa belum mengetahui dan memahami konsep awal dari materi yang akan diberikan, sehingga dibutuhkan suatu pengetahuan awal sebelum dimulainya kegiatan perkuliahan. Penelitian ini bertujuan untuk menyelidiki: (1) apakah pembelajaran dengan model Write Pair Share (WPS) dapat meningkatkan kompetensi belajar fisika mahasiswa; (2) apakah pembelajaran dengan model Write Pair Share (WPS) dapat meningkatkan kompetensi belajar fisika mahasiswa berpengetahuan awal tinggi; (3) apakah pembelajaran dengan model Write Pair Share (WPS) dapat meningkatkan kompetensi belajar fisika mahasiswa berpengetahuan awal rendah. Jenis penelitian adalah penelitian eksperimen semu dengan desain penelitian The Randomized Pretest-Posttest Control Group Design. Instrument yang digunakan adalah tes akhir berbentuk essay. Data dikumpulkan melalui pengetahuan awal sebagai pretest dan hasil belajar sebagai posttest, kemudian dianalisis dengan uji $t$. Hasil analisis data menunjukkan bahwa: (1) Terdapat perbedaan yang berarti penerapan model Write Pair Share (WPS) terhadap hasil kompetensi belajar; (2) Terdapat perbedaan yang berarti penerapan model Write Pair Share (WPS) terhadap hasil kompetensi belajar fisika siswa yang berpengetahuan awal tinggi; (3) Tidak terdapat perbedaan yang berarti penerapan model Write Pair Share (WPS) terhadap hasil kompetensi belajar fisika siswa berpengetahuan awal rendah.
\end{abstract}

Keywords :Pengetahuan Awal, Write Pair Share (WPS), kompetensi belajar fisika 


\section{PENDAHULUAN}

Fisika sebagai bagian dari Sains mempunyai peranan yang penting dalam meningkatkan kualitas sumber daya manusia terutama dalam menunjang perkembangan ilmu pengetahuan alam dan teknologi.Hal ini dapat dilihat dari penerapan ilmu fisika dalam disiplin ilmu lainnya dan aplikasinya pada perkembangan teknologi.Oleh karena itu mata pelajaran fisika perlu diperkenalkan sejak dini mulai dari SD, SMP, SMA, hingga ke perguruan tinggi.Lembaga-lembaga pendidikan diharapkan dapat melahirkan para pemikir muda yang berintelektual tinggi.

Dosen sebagai motivator dan fasilitator dalam pembelajaran diharapkan mampu menciptakan kondisi pembelajaran aktif dan kreatif sehingga tercipta interaksi yang baik antara mahasiswa dengan dosen maupun antara mahasiswa dengan sesamanya.Dosen juga diharapkan dapat memberi kesempatan kepada mahasiswanya untuk melaksanakan kegiatan bersama dalam belajar sehingga pembelajaran tidak hanya berpusat pada dosen.Mahasiswa diberi kesempatan untuk mengembangkan ide-ide kreatifnya dalam memecahkan masalah agar kemampuan berfikirnya dapat berkembang.Hal ini sejalan dengan pendapat [17] bahwa, pendidik sebagai pengelola pendidikan berperan penting dalam menciptakan dan mengoptimalkan pembelajaran dengan metode dan pendekatan pembelajaran yang dapat meningkatkan aktivitas, berpikir kritis dan kreativitas peserta didik dalam suasana yang menyenangkan.

Kebiasaan belajar mahasiswa yang hanya menunggu penjelasan materi dari dosen, tanpa ada persiapan terlebih dahulu dalam mengikuti perkuliahan diperkirakan menjadi salah satu penyebab hasil belajar yang rendah, sehingga mahasiswa menjadi pasif dan dosen mendominasi proses pembelajaran, dimana dosen menyajikan seluruh materi diselingi contoh soal dan kemudian diberikan latihan. Kegiatan belajar mengajar seperti ini membuat mahasiswa merasa tidak tertantang untuk mengembangkan kemampuan belajar kreatif dalam menyelesaikan masalah yang berkaitan dengan materi yang dipelajari. Mahasiswa menjadi kurang berminat dengan pelajaran yang diberikan sehingga pemahaman mahasiswa terhadap fisika menjadi tidak optimal dan akibatnya hasil belajar kurang memuaskan.

Pengetahuan awal (entry behavior) pada dasarnya merupakan pengetahuan atau kemampuan yang harus dimiliki mahasiswa sebelum mempelajari pengetahuan atau kemampuan baru.Dengan mengetahui kemampuan awal mahasiswa, dosen dapat menetapkan dari mana harus memulai pembelajaran. Menurut Ali [2], entry behavior pada dasarnya merupakan suatu pengetahuan dan keterampilan yang harus dimiliki terlebih dahulu oleh mahasiswa sebelum ia mempelajari pengetahuan / keterampilan baru.

Dengan adanya pengetahuan awal ini diharapkan mahasiswa mampu membangun pengetahuan/ keterampilan yang akan diberikan dosen nantinya sehingga proses belajar mengajar dapat berlangsung sebagaimana mestinya.

Pembelajaran yang diharapkan adalah sebuah proses pengalaman belajar yang menuntut mahasiswa untuk menemukan sendiri pengetahuan secara konkrit melalui panduan dan bimbingan. Pembelajaran yang demikian dapat menjadikan mahasiswa lebih paham untuk kemudian mampu mengembangkannya. Pembelajaran yang baik membina mahasiswa menjadi manusiamanusia sosial yang dapat menerima keberadaan orang lain, mampu menerima pendapat dan keputusan yang berbeda dengan keinginan pribadi, karena mahasiswa dilatih dan dibina untuk bekerjasama danmencari solusi untuk kesuksesan bersama. Salah satu alternatif untuk meningkatkan perhatian dan keterlibatan mahasiswa serta mengembangkan kemampuan berfikirnya dapat dilakukan dengan menggunakan model pembelajaran Write Pair Share (WPS) yang merupakan salah satu model pembelajaran yang berusaha meningkatkan aktivitas mahasiswa selama proses pembelajaran. 
Pada model pembelajaran Write Pair Share (WPS) mahasiswa dituntut untuk mengembangkan kemampuan berfikir dalam menyelesaikan setiap permasalahan yang diberikan oleh dosen.Dosen memberikan beberapa pertanyaan kemudian mahasiswa diminta memikirkan jawabannya terlebih dahulu dan menuliskan jawabannya di dalam lembaran kerja yang telah diberikan oleh dosen sebelumnya. Kemudian mahasiswa dipasangkan dengan teman sebangku untuk mendiskusikan jawaban yang telah ditulis.Di akhir diskusi masing-masing perwakilan kelompok mempersentasikan hasil diskusinya.Pada model pembelajaran ini mahasiswa akan lebih terlibat saat berdiskusi, karena setiap kelompok hanya terdiri dari 2 orang saja yang menyebabkan setiap anggota kelompok berpartipasi dalam menyelesaikan setiap permasalahan yang diberikan oleh dosen.

Dengan model pembelajaran Write Pair Share (WPS) dan pemberian pengetahuan awal ini diharapkan mampu memberikan suasana baru bagi mahasiswa selama proses pembelajaran, merangsang interaksi antara dosen dengan mahasiswa dan interaksi antara mahasiswa dengan mahasiswa. Berdasarkan uraian di atas penulis tertarik untuk melakukan penelitian tentang perbedaan pengetahuan awal yang dimiliki mahasiswa sebelum proses pembelajaran berlangsung dan mengetahui hasil belajar mahasiswa setelah diterapkan model pembelajaran Write Pair Share (WPS) dalam meningkatkan kompetensi belajar mahasiswa PSPB STKIP PGRI Sumatera Barat.

Berdasarkan latar belakang di atas, rumusan masalah dalam penelitian ini adalah sebagai berikut ini :

1. Apakah kompetensi belajar fisika mahasiswa yang pembelajarannya menggunakan model pembelajaran Write Pair Share (WPS) lebih tinggi dibandingkan kompetensi belajar mahasiswa yang pembelajarannya menggunakan model pembelajaran klasikal?
2. Apakah kompetensi belajar fisika mahasiswa berpengetahuan awal tinggi yang pembelajarannya menggunakan model pembelajaran Write Pair Share (WPS) lebih tinggi dibandingkan dengan kompetensi belajar mahasiswa berpengetahuan awal tinggi yang pembelajarannya menggunakan model pembelajaran klasikal?

3. Apakah kompetensi belajar fisika mahasiswa berpengetahuan awal rendah yang pembelajarannya menggunakan model pembelajaran Write Pair Share (WPS) lebih tinggi dibandingkan dengan kompetensi belajar mahasiswa berpengetahuan awal rendah yang pembelajarannya menggunakan model pembelajaran klasikal?

Berdasarkan kajian pustaka dan latar belakang, maka dapat dirumuskan hipotesis sebagai berikut :

1. Kompetensi belajar fisika mahasiswa yang proses pembelajarannya menggunakan model pembelajaran Write Pair Share (WPS) lebih tinggi dibandingkan dengan mahasiswa yang pembelajarannya menggunakan model pembelajaran klasikal.

2. Kompetensi belajar fisika mahasiswa berpengetahuan awal tinggi yang proses pembelajarannya menggunakan model pembelajaran Write Pair Share (WPS) lebih tinggi dibandingkan dengan mahasiswa berpengetahuan awal tinggi yang pembelajarannya menggunakan model pembelajaran klasikal.

3. Kompetensi belajar fisika mahasiswa berpengetahuan awal rendah yangproses pembelajarannya menggunakan model pembelajaran Write Pair Share (WPS) lebih tinggi dibandingkan dengan mahasiswa berpengetahuan awal rendah yang pembelajarannya menggunakan model pembelajaran klasikal. 


\section{METODOLOGI PENELITIAN}

\section{Jenis Penelitian}

Jenis penelitian ini adalahpenelitian eksperimental semu (Quasi Experimental Research). Tim Metodologi Penelitian [3] menyatakan, "Tujuan penelitian eksperimental semu adalah untuk memperoleh informasi yang merupakan perkiraan bagi informasi yang diperoleh dengan eksperimen yang sebenarnya dalam keadaan yang tidak memungkinkan untuk mengontrol dan/atau memanipulasikan semua variabel yang relevan". Jadi, karena yang menjadi subjek dalam penelitian ini adalah manusia, maka tidak mungkin dapat mengontrol semua variabel yang relevan kecuali beberapa dari variabel-variabel tersebut.

\section{Desain Penelitian}

Desain yang dipakai dalam penelitian ini adalah The Randomized Pretest-Posttest Control Group Design, dimana diterapkan situasi belajar yang berbeda.Adapun desain penelitian secara jelas dapat dilihat pada Tabel 1.

Tabel 1. Desain Penelitian

\begin{tabular}{|c|c|c|c|}
\hline $\begin{array}{c}\text { Kelompok } \\
\text { Penelitian }\end{array}$ & Pretest & Treatment & Posttest \\
\hline $\begin{array}{c}\text { Kelas } \\
\text { eksperimen }\end{array}$ & $\mathrm{O}_{1}$ & $\mathrm{X}$ & $\mathrm{O}_{2}$ \\
\hline $\begin{array}{c}\text { Kelas } \\
\text { kontrol }\end{array}$ & $\mathrm{O}_{3}$ & - & $\mathrm{O}_{4}$ \\
\hline
\end{tabular}

\section{Populasi dan Sampel}

Populasi dalam penelitian ini adalah seluruh mahasiswa PSPB STKIP PGRI Sumatera Barat angkatan 2014 yang mengambil mata kuliah fisika dasar tahun ajaran 2014/2015.Dalam penelitian ini digunakan kelas eksperimen dan kelas kontrol yang diambil dari populasi yang ada. Teknik pengambilan sampel yang digunakan adalah teknik Cluster Random Sampling. Padapenelitianiniterdiridaridua variabel yaitu variabel bebas dan variabel terikat.Variabel bebas dari penelitian ini adalah model pembelajaran sedangkan variable terikat yaitu kompetensi belajar mahasiswa.

\section{Instrumen Penelitian}

Keberhasilan penelitian banyak ditentukan oleh instrumen yang digunakan, karena data yang digunakan untuk menjawab masalah penelitian dan menguji hipotesis yang diperoleh melalui instrumen. [5], "Instrumen penelitian adalah alat atau fasilitas yang digunakan oleh peneliti dalam mengumpulkan data agar pekerjaannya lebih mudah dan hasilnya lebih baik, dalam arti lebih cermat, lengkap, dan sistematis sehingga lebih mudah diolah." Instrumen yang digunakan adalah tes tertulis berbentuk esai.

Data dikumpulkan dengan memberikan tes.Tes yang pertama dilakukan untuk mengukur pengetahuan awal mahasiswa dari setiap kelompok sampel.Tes ini dilakukan untuk mengelompokkan mahasiswa pada pengetahuan awal tinggi dan pengetahuan awal rendah.Tes ini dilakukan sebelum diberikan perlakuan sebagai pretest.Tes kedua dilakukan setelah mahasiswa diberi perlakuan dengan menggunakan model pembelajaran Write Pair Share (WPS).Tujuan dari tes ini adalah untuk memperoleh data hasil kompetensi belajar fisika mahasiswa sebagai posttest.

\section{Teknik Analisis Data}

Analisis data bertujuan untuk menguji apakah hipotesis kerja yang diajukan dalam penelitian ini diterima atau ditolak.Pada penelitian ini, pengaruhyang dimaksud adalah seberapa besar peningkatan penggunaan model pembelajaran Write Pair Share (WPS) terhadap kompetensi belajar fisika mahasiswadibandingkan dengan model pembelajaran klasikal secara keseluruhan, kemudian membandingkan peningkatan kompetensi belajar fisika mahasiswa berpengetahuan awal tinggi dan mahasiswa berpengetahuan awal rendah antara kedua kelas sampel.

Sebelum dilakukan uji hipotesis terlebih dahulu dilakukan uji persyaratan untuk kedua kelas, yaitu uji normalitas dan uji homogenitas. 
a. Uji Normalitas

Uji normalitas bertujuan untuk melihat apakah sampel berasal dari populasi yang terdistribusi normal atau tidak.Untuk menguji normalitas digunakan uji Liliefors.

b. Uji Homogenitas

Uji homogenitas bertujuan untuk mengetahui apakah data kelas sudah mempunyai variansi yang homogen atau tidak. Menghitung variansi masing-masing kelompok data, kemudian dihitung harga $\mathrm{F}$ dengan menggunakan rumus [20] :

$$
F=\frac{S b^{2}}{S k^{2}}
$$

c. Uji Hipotesis

Uji hipotesis bertujuan untuk mengetahui apakah hipotesis penelitian diterima atau ditolak.Berdasarkan hipotesis yang dikemukakan maka dilakukan uji satu pihak dengan uji statistik:

Ho jika $\mu_{1}=\mu_{2}$

$H i$ jika $\mu_{1}>\mu_{2}$

* Jika $\sigma_{1}=\sigma_{2}$ (varians homogen) dan $\sigma$

tidak diketahui maka dilakukan uji $t$ dengan rumus:

$$
\begin{aligned}
& t=\frac{\bar{X}_{1}-\bar{X}_{2}}{s \sqrt{\frac{1}{n_{1}}-\frac{1}{n_{2}}}} \text { dan } \\
& s^{2}=\frac{\left(n_{1}-1\right) s_{1}^{2}+\left(n_{2}-1\right) s_{2}^{2}}{n_{1}+n_{2}-2}
\end{aligned}
$$

d. Gain Ternormalisasi

Gain adalah selisih antara pretest dan posttest, gain menunjukkan peningkatan pemahaman konsep setelah pembelajaran diberikan [7]. Gain ternormalisasi digunakan untuk menghindari hasil kesimpulan yang akan menimbulkan bias pada penelitian, hal itu disebabkan karena nilai pretest keduakelas penelitian yang sudah berbeda. Menghitungskor gain ternormalisasi dengan rumus berikut:

$$
<g>=\frac{\text { skorposttest }- \text { skorpretest }}{100-\text { skorpretest }}
$$

\section{HASIL DAN PEMBAHASAN}

Data yang diperoleh dalam penelitian ini berupa hasil tes pengetahuan awal sebelum proses pembelajaran dan hasil kompetensi belajar fisika mahasiswa pada ranah kognitif yang diperoleh setelah proses pembelajaran.

1. Pengetahuan Awal

Data penelitian pada tes pengetahuan awal ini diperoleh melalui penilaian sebelum proses pembelajaran berlangsung. Penilaian ini dilakukan melalui tes awal dengan teknik tes tulis berbentuk soal essay yang diberikan pada kedua kelas sampel. Dalam penelitian ini telah dirancang soal tes pengetahuan awal yang akan digunakan nantinya untuk mengelompokkan mahasiswa kepada dua kelompok besar, yaitu mahasiswa yang berpengetahuan awal tinggi dengan mahasiswa berpengetahuan awal rendah. Bentuk tes pengetahuan yang akan diberikan dapat dilihat pada gambar di bawah.

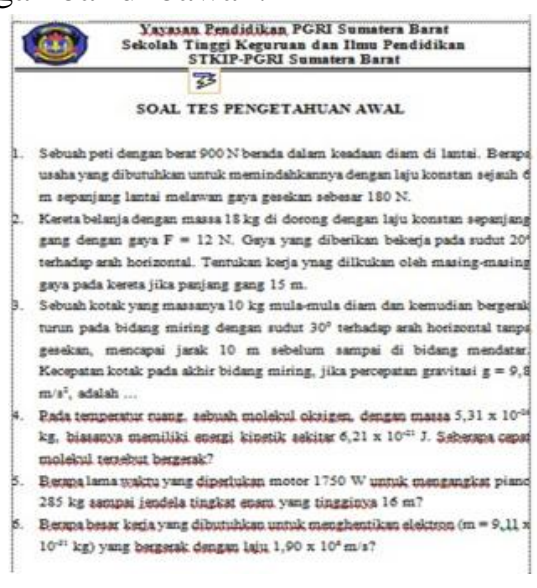

Deskipsi data penelitian variabel pengetahuan awal dapat dilihat dalam lampiran, secara keseluruhan mengungkapkan informasi tentang skor total, skor tertinggi,

\begin{tabular}{|c|c|c|c|c|c|c|c|}
\hline \multirow[t]{2}{*}{$\begin{array}{l}N \\
0\end{array}$} & \multirow[t]{2}{*}{ Statistik } & \multirow{2}{*}{$\begin{array}{l}\text { Pengetahuan } \\
\text { Awal Kelas } \\
\text { Eksperimen }\end{array}$} & \multirow{2}{*}{$\begin{array}{c}\text { Pengetahuan } \\
\text { Awal Kelas } \\
\text { Kontrol }\end{array}$} & \multicolumn{2}{|c|}{$\begin{array}{l}\text { Pengetahuan Awal } \\
\text { Kelas Eksperimen }\end{array}$} & \multicolumn{2}{|c|}{$\begin{array}{c}\text { Pengetaluan } \\
\text { Awal Kelas } \\
\text { Kontrol }\end{array}$} \\
\hline & & & & Tingei & Rendah & Tinggi & Rendah \\
\hline 1 & $\begin{array}{l}\text { Skor } \\
\text { total }\end{array}$ & 1556 & 1508 & 940 & 616 & 900 & 608 \\
\hline 2 & $\begin{array}{c}\text { Skor } \\
\text { tertingi }\end{array}$ & 52 & 50 & 52 & 40 & 50 & 42 \\
\hline 3 & \begin{tabular}{c|c|} 
Skor \\
terendah
\end{tabular} & 30 & 30 & 42 & 30 & 42 & 30 \\
\hline 4 & Mean & 40,72 & 41,39 & 46,56 & 34,89 & 46,00 & 36,78 \\
\hline 5 & Median & 41 & 42 & 46 & 36 & 46 & 36 \\
\hline 6 & Modus & $36 \operatorname{dan} 42$ & 40 & 42 & 36 & $\begin{array}{l}48,46 ; \\
\text { dan } 44\end{array}$ & 40 \\
\hline 7 & Variansi & 97,37 & 83,20 & 15,44 & 13,75 & 7,53 & 16,07 \\
\hline 8 & $\begin{array}{l}\text { Standar } \\
\text { Deviasi }\end{array}$ & 9,87 & 9,12 & $3,9 \mathrm{~B}$ & 3,71 & 2,74 & 4,01 \\
\hline
\end{tabular}
skor terendah, mean, modus dan median. Data secara keseluruhan adalah sebagai berikut :

Tabel 2. Deskripsi Data Pengetahuan Awal

2. Kompetensi Belajar Mahasiswa 
Data penelitian pada ranah kognitif ini diperoleh melalui penilaian yang dilakukan pada akhir pembelajaran. Penilaian ini dilakukan melalui tes akhir dengan teknik tes tertulis berbentuk soal essay yang diberikan kepada kedua kelas sampel. Hasil kompetensi belajar fisika mahasiswa pada ranah kognitif yang diperoleh setelah proses pembelajaran ini nantinya dikelompokan menjadi :

a. Kompetensi belajar mahasiswa yang pembelajarannya menggunakan model Write Pair Share (WPS)

Distribusi hasil kompetensi belajar mahasiswa pada kelas eksperimen yaitu yang menggunakan model pembelajaran Write Pair Share (WPS) dapat dilihat pada tabel distribusi frekuensi data berikut ini.

Tabel 3. Distribusi Frekuensi Data Hasil Belajar Mahasiswa Kelas Eksperimen

\begin{tabular}{|c|c|c|c|}
\hline Kelas interval & $\mathbf{x}$ & $\mathbf{f}$ & $\mathbf{f}_{\mathbf{k}}$ \\
\hline $35-42$ & 38,5 & 2 & 2 \\
\hline $43-50$ & 46,5 & 15 & 17 \\
\hline $51-58$ & 54,5 & 10 & 27 \\
\hline $59-66$ & & 2 & 29 \\
\hline $67-74$ & 62,5 & 2 & 31 \\
\hline $74-82$ & 78 & 5 & 36 \\
\hline
\end{tabular}

b. Kompetensi belajar mahasiswa yang pembelajarannya menggunakan model pembelajaran klasikal

Distribusi hasil kompetensi belajar mahasiswa pada kelas kontrol yaitu menggunakan model pembelajaran klasikal dapat dilihat pada tabel distribusi frekuensi data berikut ini.

Tabel 4. Distribusi Frekuensi Data Hasil Belajar Mahasiswa Kelas Kontrol

\begin{tabular}{|c|c|c|c|}
\hline Kelas interval & $\mathbf{x}$ & $\mathbf{f}$ & $\mathbf{f}_{\mathbf{k}}$ \\
\hline $32-39$ & 35,5 & 9 & 9 \\
\hline $40-47$ & 43,5 & 8 & 17 \\
\hline $48-55$ & 51,5 & 9 & 26 \\
\hline $56-63$ & 59,5 & 4 & 30 \\
\hline $64-71$ & 67,5 & 2 & 32 \\
\hline $72-79$ & 75,5 & 2 & 34 \\
\hline $80-87$ & 83,5 & 2 & 36 \\
\hline
\end{tabular}

c. Kompetensi belajar mahasiswa berpengetahuan awal tinggi yang pembelajarannya menggunakan model pembelajaran Write Pair Share (WPS)

Ringkasan analisis data skor hasil kompetensi belajar mahasiswa berpengetahuan awal tinggi yang diajar dengan menggunakan model pembelajaran Write Pair Share (WPS) dapat dilihat pada tabel distribusi data berkelompok berikut ini.

Tabel 5. Distribusi Frekuensi Data Hasil Belajar Mahasiswa Berpengetahuan Awal Tinggi Kelas Eksperimen

\begin{tabular}{|c|c|c|}
\hline Skor Nilai & $\mathbf{F}$ & $\mathbf{f}_{\mathbf{k}}$ \\
\hline $44-52$ & 6 & 6 \\
\hline $53-61$ & 6 & 12 \\
\hline $62-70$ & 2 & 14 \\
\hline $71-79$ & 2 & 16 \\
\hline $80-88$ & 2 & 18 \\
\hline
\end{tabular}

d. Kompetensi belajar mahasiswa berpengetahuan awal rendah yang pembelajarannya menggunakan model pembelajaran Write Pair Share (WPS)

Ringkasan analisis data skor hasil kompetensi belajar mahasiswa berpengetahuan awal rendah yang pembelajarannya menggunakan model pembelajaran Write Pair Share (WPS) dapat dilihat pada tabel distribusi data berkelompok berikut ini.

Tabel 6. Distribusi Frekuensi Data Hasil Kompetensi Belajar Mahasiswa Berpengetahuan Awal Rendah Kelas Eksperimen

\begin{tabular}{|c|c|c|}
\hline Skor Nilai & F & $\mathbf{f}_{\mathbf{k}}$ \\
\hline $35-43$ & 2 & 2 \\
\hline $44-52$ & 9 & 11 \\
\hline $53-60$ & 4 & 15 \\
\hline $61-69$ & 0 & 15 \\
\hline $70-78$ & 3 & 18 \\
\hline
\end{tabular}

e. Kompetensi belajar mahasiswa berpengetahuan awal tinggi yang pembelajarannya menggunakan model pembelajaran klasikal

Ringkasan analisis data skor hasil kompetensi belajar mahasiswa berpengetahuan awal tinggi yang pembelajarannya menggunakan model pembelajaran klasikal dapat dilihat pada tabel distribusi data berkelompok berikut ini.

Tabel 7. Distribusi Frekuensi Data Hasil Kompetensi Belajar Mahasiswa Berpengetahuan Awal Tinggi Kelas Kontrol

\begin{tabular}{|c|c|c|}
\hline Skor Nilai & $\mathbf{F}$ & $\mathbf{f}_{\mathbf{k}}$ \\
\hline $32-40$ & 6 & 6 \\
\hline $41-49$ & 2 & 8 \\
\hline $50-58$ & 7 & 15 \\
\hline $59-67$ & 0 & 15 \\
\hline $68-76$ & 0 & 15 \\
\hline $77-83$ & 3 & 18 \\
\hline
\end{tabular}


f. Kompetensi belajar mahasiswa berpengetahuan awal rendah yang pembelajarannya menggunakan model pembelajaran klasikal

Skor hasil kompetensi belajar mahasiswa berpengetahuan awal rendah yang pembelajarannya menggunakan model pembelajaran klasikal dapat dilihat pada lampiran.Ringkasan analisis data dapat dilihat pada tabel distribusi data berkelompok berikut ini.

Tabel 8. Distribusi frekuensi data hasil belajar mahasiswa berpengetahuan awal rendah kelas kontrol

\begin{tabular}{c|c|c|}
\hline Skor Nilai & $\mathbf{F}$ & $\mathbf{f}_{\mathbf{k}}$ \\
\hline $32-40$ & 7 & 7 \\
\hline $41-49$ & 5 & 12 \\
\hline $50-58$ & 3 & 15 \\
\hline $59-67$ & 0 & 15 \\
\hline $68-76$ & 2 & 17 \\
\hline $77-83$ & 1 & 18 \\
\hline
\end{tabular}

\section{Analisis Data}

\section{a. Hipotesis 1}

Berdasarkan uji normalitas dan uji homogenitas, terlihat bahwa kedua kelas sampel terdistribusi normal dan memiliki varians yang homogen. Untuk itu, dilakukan uji kesamaan dua rata-rata dengan menggunakan uji $t$.

Tabel 9. Ringkasan Uji Hipotesis Pertama

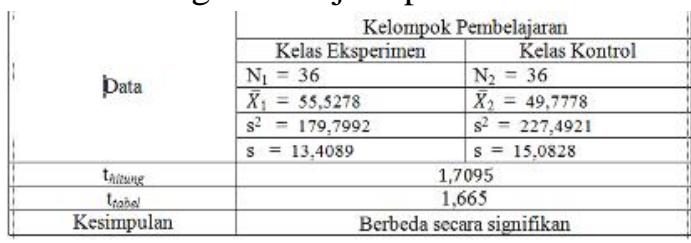

\section{b. Hipotesis 2}

Berdasarkan uji normalitas dan uji homogenitas, terlihat bahwa kedua kelas sampel terdistribusi normal dan memiliki varians yang homogen. Untuk itu, dilakukan uji kesamaan dua rata-rata dengan menggunakan uji $t$.

Tabel 10. Ringkasan Uji Hipotesis Kedua

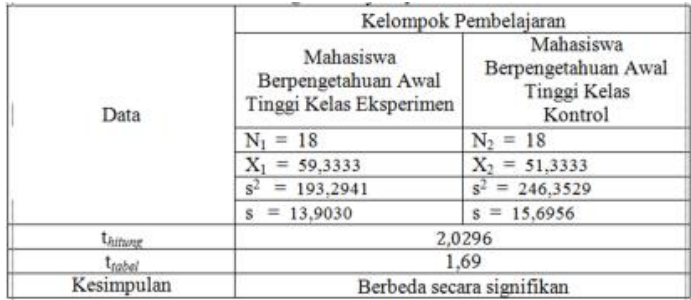

c. Hipotesis 3

Berdasarkan uji normalitas dan uji homogenitas, terlihat bahwa kedua kelas sampel terdistribusi normal dan memiliki varians yang homogen. Untuk itu, dilakukan uji kesamaan dua rata-rata dengan menggunakan uji $t$.

Tabel 11. Ringkasan Uji Hipotesis Ketiga

\begin{tabular}{|c|c|c|}
\hline \multirow{6}{*}{ Data } & \multicolumn{2}{|c|}{ Kelompok Pembelajaran } \\
\hline & $\begin{array}{c}\text { Mahasiswa } \\
\text { Berpengetahuan Awal } \\
\text { Tinggi Kelas Eksperimen }\end{array}$ & $\begin{array}{c}\text { Mahasiswa } \\
\text { Berpengetahuan Awal } \\
\text { Tinggi Kelas } \\
\text { Kontrol }\end{array}$ \\
\hline & $\mathrm{N}_{1}=18$ & $\mathrm{~N}_{2}=18$ \\
\hline & $\bar{X}_{1}=51,7222$ & $\bar{X}_{2}=48,2222$ \\
\hline & $s^{2}=146,2124$ & $\mathrm{~s}^{2}=216,8889$ \\
\hline & $s=12,0918$ & $s=14,7271$ \\
\hline$t_{\text {hituoge }}$ & \multicolumn{2}{|c|}{0,7793} \\
\hline$t_{\text {sabel }}$ & \multirow{2}{*}{\multicolumn{2}{|c|}{1,69}} \\
\hline Kesimpulan & & Tidak berbeda secara signifikan \\
\hline
\end{tabular}

Berdasarkan deskripsi data yang telah dipaparkan sebelumnya, terlihat bahwa nilai rata-rata kompetensi belajar fisika mahasiswa pada ranah kognitifkelas eksperimen yang diberi perlakuan model pembelajaran Write Pair Share (WPS) lebih tinggi dibandingkan dengan kelas kontrol yang menggunakan model pemb elajaran klasikal. Hal ini sesuai dengan hasil pengujian hipotesis, yang diketahui bahwa penggunaan model pembelajaran Write Pair Share (WPS) memberikan pengaruh yang cukup besar terhadap kompetensi belajar mahasiswa dibandingkan model pembelajaran klasikal, baik pada kelompok mahasiswa yang mempunyai pengetahuan awal tinggi maupun kelompok mahasiswa yang mempunyai pengetahuan awal rendah. Hal ini menunjukkan bahwa penggunaan model pembelajaran Write Pair Share (WPS) dapat meningkatkan kompetensi belajar mahasiswa secara keseluruhan pada mata pelajaran fisika dasar. 


\section{KESIMPULAN}

Penelitian ini merupakan penelitian yang membandingkan kompetensi belajar fisika mahasiswa yang menggunakan model pembelajaran Write Pair Share (WPS) dan model pembelajaran klasikal dengan memperhitungkan pengetahuan awal mahasiswa terhadap mata pelajaran fisika. Pengetahuan awal mahasiswa diperoleh dari hasil tes yang dilakukan di awal pembelajaran, sedangkan hasil kompetensi mahasiswa diperoleh dari tes yang dilakukan pada akhir pembelajaran.Penerapan model pembelajaran Write Pair Share (WPS) ini dibantu dengan menggunakan LKS yang telah dipersiapkan oleh peneliti sebelumnya.

\section{DAFTAR PUSTAKA}

[1] Arikunto, S. 2005. Dasar Evaluasi Pendidikan.Jakarta : Bumi Aksara.

[2] Asmiati. 2008. Upaya Peningkatan Aktivitas dan Hasil Belajar Matematika Siswa Menggunakan Model Pembelajaran Write Pair Share. Skripsi tidak diterbitkan. Padang: Jurusan Pendidikan Matematika UNP.

[3] Balitbang Depdiknas. 2002. Kurikulum Berbasis Kompetensi. Jakarta : Balitbang Depdiknas.

[4] Carleton Collage. 2007. InteractiveTPS.http://serc.carleton.e du/introgeo/interactive/tpshare.html. didownloadtanggal 5 Maret 2011.

[5] Depdiknas. 2003. Standar Kompetensi Mata Pelajaran Sekolah Menengah Atas dan Madrasah Aliyah.Jakarta: Puskur Balitbang Depdiknas.

... 2005. Pedoman Khusus Pengembangan Silabus dan Penilaian Mata Pelajaran Fisika. Jakarta : Dirjen Dijti.

[7] Ibrahim, M. 2001. Pembelajaran Kooperatif. Surabaya : UNESA.

[23] Supriyono,K. 2003. Strategi Pembelajaran Fisika. Malang : jurusan Fisika.
[8] Irianto, A. 2007. Statistik. Konsep Dasar dan Aplikasinya. Jakarta: Kencana.

[9] Ledlow, S. 2001. Using Think Pair Share in The College Classroom. Arizona State University.http://clte.asu.edu/active/ usingtps.pdf.didownload tanggal 5 Maret 2011.

[10] Lie, A. 2002. Cooperative Learning.Jakarta : Grasindo.

[11] Mardapi. 2001. Laporan Studi : Pola Induk Pengembangan Silabus Berbasis Kemampuan Dasar Sekolah Menengah Umum. Jakarta : Dikmenum.

[12] Muliyardi. 2003. Strategi Belajar Mengajar Matematika. Padang : FMIPA.

[13] Nasution. 2000. Teknologi Pendidikan. Bandung: Jemmars

[14] Prayitno, E. 2003. Materi Diklat Pedoman Pengembangan Sistem Penilaian. Yogyakarta: FMIPA UNY.

[15] Safari. 2008. Analisis Butir Soal. Jakarta: Departemen Pendidikan dan Kebudayaan.

[16] Sagala, S. 2003. Konsep dan Makna Pembelajaran. Bandung: Alfabeta.

[17] Sanjaya, W. 2006. Pembelajaran dalam Implementasi Kurikulum Berbasis Kompetensi. Bandung: Kencana Prenada Media Group.

[18] Slameto. 2002. Evaluasi Pendidikan. Salatiga: Bumi Aksara.

[19] Sofa. 2008. Aspek Penilaian Dalam KTSP.

Http://massofawordpress.com. Didownload tanggal 29 Maret 2011.

[20] Sudjana, N. 2000. Dasar-dasar Proses Belajar Mengajar. Bnadung : Remaja Rosdakarya.

[21] .................... 2002. Penilaian Hasil Proses Belajar Mengajar.Bandung : Rosdakarya.

[22] Sugiyono. 2007. Metode Penelitian Kuantitatif Kualitatif dan $R \& D$. Bandung.

Alfa

[24] Suryabrata, S. 2004. Metodologi Penelitian. Jakarta: Raja Grafindo Sejahtera.

[25] Trisna, S. 2009. Pengaruh Penerapan Model Pembelajaran Write Pair 
Share (WPS) Terhadap Hasil Belajar

Fisika Siswa. Skripsi tidak

diterbitkan. Padang: Jurusan Pendidikan Fisika UNP.

[25] Yamin, M. 2004. Pengembangan Kompetensi Pebelajar. Jakarta :Universitas Indonesia (UI-Press).
[27] Yetti. 2007. Upaya Peningkatan Aktivitas dan Hasil Belajar Matematika Siswa Melalui Model Pembelajaran Kooperatif Tipe WPS (Write-Pair-Share). Skripsi tidak diterbitkan. Padang: Jurusan Pendidikan Matematika. UNP. 